\title{
JUBILEE OF THE SCIENCE MASTERS' ASSOCIATION
}

\section{BY G. FOWLES}

\author{
Chairman of the Association, 1940-45
}

$\mathrm{T}$ 'HE Science Masters' Association celebrates its jubilee at the annual meeting being held in London during January 2-5. A commemorative dinner has been arranged at which many distinguished guests will be present.

At the time of its foundation in 1900, membership of the Association was open to masters in public schools only. However, in the eventful year 1918 the more progressively minded of the Committee came to the conclusion "that we owe it to the good of the nation to accept members from other types of school". In 1919, against much opposition, these men of vision won their point. Rarely has such a democratic gesture proved so great a success. The Association grew rapidly; the membership, less than 350 in 1919 , had by 1939 risen to 2,600 ; in all directions there was recognition and welcome. The universities, old and new, the great scientific institutions and the leaders of industry alike, offered help and hospitality. In turn, a succession of the leading men of science in Great Britain willingly accepted office as president and gave of their best. Probably the single-minded aim of the Association, "to promote the teaching of science in schools", and the absence of trade union status and outlook and of any ulterior motive, had something to do with this; for it allowed public men and officials to attend the meetings and express their views. Prominent among such regular visitors in the early 'twenties were Sir Richard Gregory, Sir Harold Hartley, and Profs. H. E. Armstrong and A. Smithells. With their scholarship, their wider outlook and their warm attitude to the cause, their very presence at the conferences did much to raise the level of discussion and to broaden the outlook. From the beginning, H.M. inspectors of schools were enthusiastic and helpful members. The social contact permitted of informal talks which made official negotiations all the smoother. In recognition of their friendly help, the Association has made four of their number honorary members : E. G. (now Sir Graham) Savage, F. B. Stead, C. J. R. Whitmore and A. R. Marshall.

Since it is generally recognized that science is a dominant factor in the world of to-day, teachers instinctively realize that their attitude to it and to its teaching is of vital significance. Yet science is a comparatively new subject in the schools. The opportunity, therefore, of exchanging ideas and experience and of discussing methods of teaching afforded by the Science Masters' Association furthered its rapid growth. Still, I believe that much of the present prosperity is due to the sound planning of the early leaders and their successors. On four of these the Association bestowed its greatest honour: each in his day filled the office of president. They are Archer Vassall and C. L. Bryant, both of Harrow, C. E. (now Sir Cyril) Ashford of Dartmouth, and G. H. J. Adlam of the City of London School. These pioneers took a large share in building the two pillars of the Association, namely, the annual conference and the Association's journal, the School Scipnce Review. The latter owes much to the ability and devotion of its founder and first editor, G. H. J. Adlam. The first issue, a booklet of 32 pages, appeared in 1919 ; the sixty-fifth, issued in 1939 , contained 160 pages of reading matter. Adlam was responsible fo: the first 103 numbers, and on his death in 1941 Spenser R. Humby, of Winchester, was appointec editor. All are pleased that while he retains the arrangement and keeps to the tradition of Adlam he from time to time adds ideas of his own. Mos: of the contributions are by members; but, wher necessary, outside specialists are called upon tc give expositions of difficult problems and of new advances. In addition, the journal contains the presi dential and other addresses, records of meetings descriptions of school-made apparatus and of new experiments. Those experiments recorded in the journal which seemed worthy of perpetuation have been suitably arranged in book form ; so far, five of these "Scierre Masters' Books" have been published

Adlam's achievement in raising the School Science Review to the foremost place among journals of its class was so remarkable and so beneficial to science teaching that news of it spread afar. In 1934, when his work was recognized by the award of the O.B.E., the Association was indeed proud. Hundreds of members helped Adlam by writing articles, reviewing books, giving specialist advice and answering the questions of correspondents. If from these I single out for remembrance the name of Bernard Neville of William Ellis School, I am sure none would demur. Neville had a brilliant brain, and his physical affliction-he was a cripple-seems to have imbued him with a more than ordinary desire to serve his fellow-men.

The annual conference of the Association, usually held in the Christmas holidays, lasts for three days. The president delivers his address and well-known science specialists give lectures, so that the conference becomes in part a refresher course. Members exhibit school apparatus and show novel experiments and devices. The Committee arranges discussions and visits to places of scientific interest. Publishers and instrument makers display their wares and demonstrate the working of new apparatus. Opportunities for social contacts and for informal discussions abound. The many who attend these conferences speak appreciatively of the stimulation and enjoyment they bring. Among those attending the Jubilee Conference are the president, Sir Robert Robinson, the Dean of St. Paul's, who is to give an address on "Knowledge, Religious and Scientific", A. H. T. Glover, who is to deliver the Science and Citizenship Lecture, and Profs. C. K. Ingold, C. A. Coulson and J. Z. Young. The Science Masters' Association has already done much good work; still more work and difficult problems lie ahead. These latter include: the problem of science for the classical sixth form, the perennial question of the admission of women members, the role of the broadcast and the film strip in schools, and the machinery for running the Association. The recent Education Act created the secondary modern schools, and teachers in them were immediately welcomed into the Association and offered the help of its accumulated experience. In a few years time, this new class could easily outnumber the present members and determine the policy of the Association-a problem indeed. Yet I look to the future with confidence. In $H$. P. Ramage, of Grosham's School, Holt, we have a leader of tried worth. Already in one office or another he has served for fourteen years. During the War he did more than any other to keep the Association in being; it is fitting that in its jubileo year he should be chairman of the Association. 